\title{
Survival assessment of Salmonella enterica in inoculated pork salami
}

\section{Avaliação da sobrevivência de Salmonella enterica inoculada em salame de carne suína}

\author{
Gabriela Orosco Werlang ${ }^{1 *}$; Tatiana Regina Vieira ${ }^{2}$; Eduardo de Freitas Costa ${ }^{3}$; \\ Marisa Cardoso ${ }^{4}$
}

\section{Highlights:}

Salmonella enterica is able to multiply during the salami fermentation stage.

Salmonella enterica survives the drying step of artificially contaminated salami.

TAL agar is more efficient than XLD in recovering injured Salmonella cells.

\begin{abstract}
Pork salami is an embedded, cured and ripened product commonly consumed in Brazil, and the presence of Salmonella enterica has already been reported in this product. During its preparation, the microbiological safety depends on the meat quality, addition of ingredients with antimicrobial activity, hygiene during processing, $\mathrm{pH}$ and water activity ( $\mathrm{Aw}$ ) reduction during maturation. In Brazil, the maturation protocol has not been determined in food regulation; therefore, the objectives of this study were (a) to identify the fermentation and drying phases during salami maturation; (b) to test the survival of $S$. enterica during salami processing; and (c) to compare xylose lysine deoxycholate (XLD) and thin agar layer (TAL) agar for recovering Salmonella. The salami samples were prepared with a cocktail of S. enterica strains, fermented at $30^{\circ} \mathrm{C}$ and dried at $20^{\circ} \mathrm{C}$ with controlled relative humidity (RH). Periodic sampling for $S$. enterica quantification and $\mathrm{Aw}$ and $\mathrm{pH}$ analyses were performed during maturation, and curves were constructed. Fermentation occurred during the first 66 hours, and the $\mathrm{pH}$ decreased while the population of $S$. enterica increased over the first 21 hours. The drying step was able to reduce the bacterial population by approximately $5 \log$ CFU after 875 hours, reaching an Aw of less than 0.78 . However, elimination of $S$. enterica was not achieved. For Salmonella recovery, TAL agar was more efficient than XLD agar.
\end{abstract}

Key words: Fermentation. Maturation. Microorganism. Ripening. Sausage.

\section{Resumo}

O salame de carne suína é um produto embutido, curado e maturado comumente consumido no Brasil no qual a presença de Salmonella enterica tem sido relatada. Durante a sua elaboração, a segurança microbiológica depende da qualidade da carne, adição de ingredientes com atividade antimicrobiana,

${ }^{1}$ Dra , Laboratório de Medicina Veterinária Preventiva, Faculdade de Veterinária, Universidade Federal do Rio Grande do Sul, UFRGS, Porto Alegre, RS, Brasil. E-mail: gwgabiwer@gmail.com

2 Discente do Curso de Doutorado do Programa de Pós-Graduação em Ciências Veterinárias, Faculdade de Veterinária, UFRGS, Porto Alegre, RS, Brasil. E-mail: tatianareginavieira@gmail.com

3 Pós-Doutor, Laboratório de Epidemiologia, Faculdade de Veterinária, UFRGS, Porto Alegre, RS, Brasil. E-mail: eduardo.costa@ ufrgs.br

${ }^{4}$ Prof $^{\mathrm{a}}$ Dra $^{\mathrm{a}}$, Departamento de Medicina Veterinária Preventiva, Faculdade de Veterinária, UFRGS, Porto Alegre, RS, Brasil. E-mail: mcardoso@ufrgs.br

* Author for correspondence 
higiene durante a produção, redução de $\mathrm{pH}$ e atividade de água (Aw) durante a sua maturação. $\mathrm{O}$ protocolo de maturação ainda não está determinado na legislação brasileira; portanto o estudo objetivou: (a) identificar as fases de fermentação e dessecação durante a maturação de salame; (b) testar a sobrevivência de $S$. enterica durante o processamento de salame e (c) comparar os meios de cultura xilose lisina dextrose (XLD) e thin agar layer (TAL) para recuperação de células do referido microorganismo. Os salames foram elaborados com um coquetel de $S$. enterica e submetidos à fermentação em $30^{\circ} \mathrm{C}$ e secagem a $20^{\circ} \mathrm{C}$ com umidade relativa (UR) controlada. Amostragens periódicas para quantificação de $S$. enterica, análises de Aw e pH foram realizadas durante a maturação e as curvas foram construídas. A fermentação ocorreu nas primeiras 66 horas, quando houve queda do $\mathrm{pH}$ do salame; entretanto $S$. enterica aumentou sua população nas primeiras 21 horas. A etapa de dessecação foi capaz de reduzir aproximadamente $5 \log$ UFC da população bacteriana em 875 horas, alcançando Aw menor que 0,78 , mas não foi capaz de eliminar o micro-organismo do alimento. Para enumeração do micro-organismo, o meio sólido TAL foi mais eficiente na recuperação das células submetidas à maturação quando comparado ao ágar XLD comumente utilizado.

Palavras-chave: Dessecação. Embutido. Fermentação. Maturação. Micro-organismo.

\section{Introduction}

Salami is a type of sausage consisting of cured and matured meat, mainly pork, and is usually consumed raw by a large part of the Brazilian population. Curing, fermentation and drying are mandatory stages of the manufacturing process; however, Brazilian food regulation does not provide for a specific protocol. Thus, optional ingredients and the duration of fermentation and drying steps are at the discretion of the manufacturer, provided that by the end of the process, the product achieves the maximum permitted values of humidity $(40 \%)$ and water activity (Aw 0.90) determined by Brazilian regulation (Instrução Normativa $n^{\circ} 22,2000$ ).

Between 2009 and 2018, Salmonella enterica was the second leading cause of foodborne disease outbreaks in Brazil. This pathogen was reported in $11.3 \%$ of the confirmed outbreaks, a frequency that is very likely underestimated (Ministério da Saúde [MS], 2019). There are reports on the presence of S. enterica in salami at the retail level (Werlang, Haubert, Peter, \& Cardoso, 2019), although the Brazilian standard for meat products is the absence of $S$. enterica in a 25 gram sample (Resolução RDC $\left.n^{\circ} 12,2001\right)$. One possible reason for cases of Salmonella contamination in salami may be the occurrence of failures in the antimicrobial hurdles (low $\mathrm{Aw}$ and $\mathrm{pH}$ ) imposed during manufacturing. In addition, bacteria may differ in behavior in distinct foodstuffs, or they may develop cellular mechanisms of adaptation to environmental stresses (Álvarez-Ordóñez, Fernández, Bernardo, \& López, 2010; Nightingale, Thippareddi, Phebus, Marsden, $\&$ Nutsch, 2006).

Different mathematical models allow predicting the inactivation of bacteria and their probability of growth in foodstuffs under adverse conditions such as unfavorable $\mathrm{pH}$ and Aw values (Coroller, KanKing-Yu, Leguerinel, Mafart, \& Membré, 2012). In this sense, the adoption of methodologies that are able to recover possible injured bacterial cells after the manufacturing processes is key in order to generate real bacterial behavior data. Selective culture media used for enumeration of $S$. enterica can inhibit the growth of injured cells. Therefore, methodologies that combine layers of nonselective agar with layers of selective solid media, such as Spray, Overlay, and TAL, have shown better results in the recovery of $S$. enterica (Back, Kim, Park, Chung, \& Kang, 2012; Wu, Fung, \& Kang, 2001). Among these methodologies, the use of xylose lysine deoxycholate (XLD) agar containing a thin overlay of tryptic soy agar (TSA), called thin agar layer (TAL), was shown to be efficient in recovering cells injured by freezing, acid, and heat. Moreover, TAL was reported to be easy to prepare and presented good performance in $S$. enterica isolation (Chang, Mills, \& Cutter, 2003; Wu et al., 
2001; Kang \& Fung, 2000). Since the decrease in $\mathrm{pH}$ and $\mathrm{Aw}$ values during the maturation process of salami can cause injuries to $S$. enterica cells, TAL is expected to improve their recovery, generating better estimates of contamination in this foodstuff.

In Brazil, there are no data on the survival of $S$. enterica throughout the manufacturing stages of salami. Thus, the aims of this study were (a) to identify the fermentation and drying phases during the salami maturation process; (b) to assess the survival of $S$. enterica during the maturation process; and (c) to compare XLD and TAL agar for recovering $S$. enterica from artificially contaminated salami.

\section{Material and Methods}

\section{Preparation of the Salmonella cocktail}

Four strains of $S$. enterica from the culture collection of the Preventive Veterinary Medicine Laboratory of the Federal University of Rio Grande do Sul were selected: two strains of serovar Typhimurium (PL10 and PL1048); S. Infantis (PL7); and S. Derby (PL764). The reference strain S. Typhimurium ATCC 14028 was also added to the cocktail.

The selected strains were individually adapted in BHI broth supplemented with $1 \%$ glucose. Afterwards, they were subjected to two consecutive growth rounds in 10 and $20 \mathrm{~mL}$ of $\mathrm{BHI}$ broth (Oxoid, Basingstoke, UK) incubated at $37^{\circ} \mathrm{C} \pm 2$ for 18 hours. Next, the cultures were centrifuged at $3,800 \times \mathrm{g}$ for 40 minutes. The supernatant was discarded, and the cell pellet was resuspended in 2 $\mathrm{mL}$ of $0.85 \% \mathrm{NaCl}$. The inoculum was adjusted to a concentration of approximately $10 \log \mathrm{CFU} \mathrm{mL} \mathrm{mL}^{-1}$ on the McFarland scale. The cocktail of the five strains was prepared by transferring a $2 \mathrm{~mL}$ aliquot from each strain suspension (approximately $10 \log \mathrm{CFU}$ $\left.\mathrm{mL}^{-1}\right)$ to a sterile tube.

\section{Salami manufacturing}

The ingredients for the minced meat mass were based on typical recipes of industrialized salami in Brazil: $85 \%$ pork (shoulder); $11 \%$ bacon; $2 \%$ sodium chloride; $0.96 \%$ spices; $0.90 \%$ glucose; $0.03 \%$ curing salts (nitrate and sodium nitrite); $0.11 \%$ erythorbate and sodium glutamate; and $0.02 \%$ Lyocarni starter culture (SBM-11, Sacco, Campinas, Brasil). After the ingredients were weighed, mixed and homogenized, the Salmonella cocktail was added to the dough at a final concentration of $\sim 10^{7}$ $\mathrm{CFU} \mathrm{g}^{-1}$ for the preparation of contaminated salami. Fifty salami pieces were prepared by inserting the mixture into natural casings. Each salami piece measured approximately $15 \mathrm{~cm}$ and weighed approximately 200 g. After encasing, individual salami pieces were identified and hung on stainless steel rods inside a maturation chamber $(100 \mathrm{~cm}$ x 85 $\mathrm{cm} \times 60 \mathrm{~cm})$. The internal space of the maturation chamber was divided into two areas (A and B) to allow the simultaneous sampling of salami units ( $n=23$ ) belonging to the two replications of the experiment. At each sampling time, determined after conducting a pilot test (data not shown), one salami piece from area $\mathrm{A}$ and one from area $\mathrm{B}$ were collected. The samplings for microbiological and $\mathrm{pH}$ analysis were first set at short intervals of 0 to 12 hours (11 sampling events performed from the $1^{\text {st }}$ to the $4^{\text {th }}$ day of maturation). Afterwards, the intervals were set at 48 to 72 hours (8 samplings performed from the $5^{\text {th }}$ to the $24^{\text {th }}$ day of maturation), followed by long intervals of 72 to 120 hours (four samplings performed from the $25^{\text {th }}$ to the $39^{\text {th }}$ day of maturation). For the Aw analysis, one salami unit was taken at zero, 192, 528 and 810 hours.

\section{Identification of salami maturation stages}

Salami pieces underwent maturation for 941 hours under a controlled temperature and relative humidity (RH): $30^{\circ} \mathrm{C}$ during fermentation, with $99 \%$ to $95 \% \mathrm{RH}$, and $20^{\circ} \mathrm{C}$ during the drying stage, 
with the RH gradually reduced from $95 \%$ to $70 \%$. The fermentation stage occurred from zero hours until the salami presented a $\mathrm{pH}$ equal to or less than 5.4. Thereafter, the drying stage began and lasted until the end of maturation.

\section{Microbiological and physical-chemical analysis}

Enumeration of Salmonella enterica and $\mathrm{pH}$ analysis

For each salami piece, two internal portions of the salami were taken after removal of the casing: $20 \mathrm{~g}$ was added to $200 \mathrm{~mL}$ of distilled water for $\mathrm{pH}$ analysis, and $25 \mathrm{~g}$ was added to $225 \mathrm{~mL}$ of $1 \%$ buffered peptone water (BPW) for quantification of $S$. enterica. Both portions were homogenized individually for one minute in a stomacher-type homogenizer (LS 1901, Logen Scientific, Brazil).

For enumeration of $S$. enterica, serial dilutions in $9 \mathrm{~mL}$ of the initial suspension were performed in $0.1 \%$ peptone water $(0.1 \% \mathrm{PW})$. From each dilution, $0.1 \mathrm{~mL}$ was inoculated in duplicate on the surface of XLD agar plates (Oxoid). In parallel, aliquots of equal volume were transferred onto TAL agar (XLD agar + TSA agar, Oxoid), according to Kang and Fung (2000). After incubation for 48 hours at $35^{\circ} \mathrm{C}$, typical colonies (red with black center) were counted. Three typical colonies from the XLD and TAL agar were transferred to TSA agar and confirmed phenotypically for Salmonella spp. with the following biochemical tests: triple sugar iron agar and lysine iron agar; urea broth and IMViC (indole, methyl red, Voges-Proskauer and citrate), according to Quinn et al. (2011). The confirmation of the genus was carried out by the agglutination test with polyvalent somatic anti-Salmonella spp. (Probac, São Paulo, Brazil).

The $\mathrm{pH}$ analysis was performed directly in the homogenate using a pH meter DM-22 (Digimed, São Paulo, Brazil) previously calibrated and used only for contaminated samples. For each sample, three measurements were made, and the average of the readings was calculated. The electrode decontamination was performed with a $20 \%$ hydrochloric acid solution (Merck, Darmstadt, Germany) after each measurement round.

\section{Water activity analysis}

Aw analysis was performed in four salami pieces at zero, 192, 528, and 810 hours. Three grams of each sample was macerated and placed in disposable ePW capsules (Novasina, Lachen, Switzerland); the Aw was measured in a Lab Touch - Aw device (Novasina). The analysis was performed at $25^{\circ} \mathrm{C}$ in duplicate for each sample unit of salami, and then, the average of the two readings was calculated.

\section{Statistical analysis}

Performance comparison between XLD and TAL

The microbial population density log (CFU $\mathrm{g}^{-1}$ ) was calculated by multiplying the number of colonies by the inverse of the dilution. The $S$. enterica mean concentrations in XLD and TAL were compared by a generalized linear mixed model using the media (XLD or TAL) as a fixed effect and the paired samples in time as considered a cluster, and it was included as a random effect. The model was assessed with a $95 \%$ confidence level.

\section{Water activity $(A w)$ estimation from the samples}

It was assumed that the Aw reduction follows a density-dependent rate described by the following differential equation:

$$
\frac{d y}{d t}=-\beta y,
$$

where is a constant (measure unit 1/time) fitted by the minimization of the mean squared error.

Solving eq 1 using the initial values observed in the experiment, the following was obtained:

$$
y_{t}=y_{0} \cdot e^{-t \beta} \text {, }
$$


where $t$ is the time in hours, $y_{0}$ is the Aw at time zero and $\beta=0.000244$ hours $^{-1}$.

The average daily Aw loss from time zero until the end of maturation was obtained by dividing the total Aw variation by the total maturation time in hours.

\section{Results and Discussion}

In salami manufacturing, fermentation and drying are necessary steps to achieve the typical characteristics of the product. Moreover, these stages are used for the control of pathogens in products such as salami, which does not undergo heat treatment (Lindqvist \& Lindblad, 2009). However, because of the lack of standardization in these steps, salami available in the Brazilian retail market may present physical-chemical parameters outside of the permitted limits (Caccioppoli, Custódio, Vieira, Coelho, \& Glória, 2006; Werlang et al., 2019).

In our study, the fermentation step occurred in the period corresponding to the first 66 hours, in which the $\mathrm{pH}$ dropped from 6.69 to 5.4. Afterward, the drying step began ( 875 hours), and the $\mathrm{pH}$ decreased until reaching 5.05 , followed by an increase to 5.84 at the end of the maturation process. The end of maturation was determined by the loss of the product characteristics due to the very low moisture, which occurred after 941 hours. The decline in $\mathrm{pH}$ during the initial hours of fermentation is key to ensuring color development and stabilization as well as the formation of desirable compounds for salami flavor. Moreover, the decrease in $\mathrm{pH}$ until reaching a value close to 5.3 , which is equivalent to the meat's isoelectric point, signified the beginning of the drying stage. This stage, in turn, ensured the continuity of the technological process since water migration begins from the inner part towards the encased surface (Chasco, Lizaso, \& Beriain, 1996). The duration of the fermentation stage, as well as the increase in $\mathrm{pH}$ presented throughout the process, were in line with studies conducted in Brazilian salami (Barbosa, Todorov, Jurkiewicz, \& Franco, 2015). Moreover, the increase in $\mathrm{pH}$ has been related to the development of lactate-oxidizing fungi on the food surface during the process (Mauriello, Casaburi, Blaiotta, \& Villani, 2004).

During the drying stage, the Aw gradually decreased, and salami pieces presented Aw values of 0.9570 at zero hours, 0.913 at 192 hours, 0.836 at 528 hours and 0.783 at 810 hours. The analysis by differential equation of the values assessed in the four sampling points allowed determining the Aw at every hour of the maturation process. Thus, at the beginning of the drying stage, after 67 hours of maturation, the salami presented an Aw of 0.9417 and reached an Aw of 0.90 at 252 hours. The average daily decrease in the Aw value was calculated to be 0.0050. Most microorganisms displayed maximum growth between Aw values of 0.990 and 0.995 ; thus, the reduced Aw value increases the lag phase of the growth curve, leading to a decrease in bacterial multiplication (Beales, 2004).

The quantity of $S$. enterica at zero hours was $7.04 \log \mathrm{CFU} \mathrm{g}^{-1}$ and $7.13 \log \mathrm{CFU} \mathrm{g}^{-1}$ on XLD and TAL agar, respectively. The number of $S$. enterica increased until 21 hours of fermentation, reaching 8.27 log CFU g ${ }^{-1}$ on XLD agar and 8.37 log CFU $\mathrm{g}^{-1}$ on TAL agar. Afterwards, a decline until $2.59 \mathrm{log}$ CFU g ${ }^{-1}$ (XLD) and $3.03 \log \mathrm{CFU} \mathrm{g}^{-1}$ (TAL) was observed after 941 hours of maturation. Therefore, the reduction in the $S$. enterica population after fermentation was equivalent to $5.67 \log \mathrm{CFU} \mathrm{g}^{-1}$ and $5.33 \log$ CFU g ${ }^{-1}$ on XLD and TAL, respectively. The $S$. enterica reduction observed in our study was greater than that in other reported fermentation and drying protocols (Mataragas et al., 2015). It is worth noting that the maturation time in our study was 39 days, which is longer than the period of 14 to 28 days usually adopted in the manufacturing of Brazilian salami (Fieira, Marchi, Marafão, \& Alfaro, 2018; Santa et al., 2014)

Studies suggest that the maturation of the salami is completed when the product reaches Aw values 
below 0.87 (Campagnol et al., 2011; Cirolini et al., 2010); however, the Brazilian regulation allows Italian salami to present an Aw value of 0.90 (Instrução Normativa $\mathrm{n}^{\circ} 22,2000$ ). In our study, when the salami reached an Aw of 0.90 (at 252 hours of maturation), a $S$. enterica population above $6 \log$ CFU g ${ }^{-1}$ was still present. It should be noted that the initial $S$. enterica concentration was increased in our study to simulate a worse scenario of contamination. Although the initial contamination levels of raw pork are unlikely to be close to $7 \mathrm{log}$ CFU g-1 the occurrence of temperature abuse and cross-contamination during processing can increase the initial bacterial load to values higher than those usually reported (Nightingale et al., 2006).

Pathogens subjected to environmental stress, such as changes in $\mathrm{pH}$ and Aw during the maturation of sausages, present different patterns of cell damage and death. As a result, the recovery of injured cells may be difficult, which may cause inaccuracies in determining the behavior of pathogens (Hwang et al., 2009; Riordan et al., 1998). Injured cells are usually repaired and become functionally normal after exposure to favorable environmental conditions, such as cultivation in a nonselective medium; however, they may not recover if transferred directly to selective media (Kang \& Fung, 2000). In the present study, to minimize this failure, TAL agar was used. By including an overlay of TSA agar, both types of cells (injured and noninjured) were expected to grow and form typical colonies. In fact, the use of TAL agar enabled a higher mean recovery of $S$. enterica cells, at approximately 0.14 $\log$ CFU g ${ }^{-1}$, than that with XLD agar $(p<0.05)$. In contrast, Ferreira, Horvath and Tondo (2013) found no significant difference in the recovery of injured cells from $S$. Enteritidis, $S$. Typhimurium and $S$. Bredeney when XLD and TAL agar were compared. Other studies, however, reported results that corroborate the greater recovery of injured $S$. Typhimurium in associated culture media such as TAL (Chang et al., 2003; Kang \& Siragusa, 1999;
Kang \& Fung, 2000; Wu et al., 2001). According to Nightingale et al. (2006), the improvement achieved in Salmonella quantification when using selective culture media associated with nonselective media suggests the presence of injured but viable cells. These findings highlight the importance of using protocols that are capable of accurately evaluating the survival of $S$. enterica during manufacturing processes of ready-to-eat (RTE) products.

In addition to the fact that the formulation and maturation time of salami manufacturing are not determined in Brazilian food regulation (Instrução Normativa $\mathrm{n}^{\circ} 22,2000$ ), other factors may influence the processing, including the competitive microbiota present in raw meat and differences in the Aw and initial $\mathrm{pH}$ between salami units belonging to the same batch or to different batches (Roccato et al., 2017). Thus, it is difficult to determine a processing protocol for salami that excludes the risk of $S$. enterica survival. For this purpose, mathematical models have been proposed to predict the behavior of microorganisms in complex foods. In this sense, mathematical modeling should be applied to the data obtained in this study to predict pathogen behavior and analyze the risks.

\section{Conclusion}

In the manufacturing of salami in this study, the fermentation step lasted 66 hours and the drying step lasted 875 hours. After 66 hours of fermentation, the $\mathrm{pH}$ decreased from 6.69 to 5.4, while the S. enterica count increased in the first 21 hours. At the end of the drying stage (after 39 days of maturation), the Aw was lower than 0.78 , and a reduction of approximately $5 \log$ CFU of the initial $S$. enterica population in the mass of the salami was observed. However, total elimination of the bacteria was not achieved at the end of the process. TAL agar was more efficient in recovering Salmonella cells after the maturation stage than XLD agar. 


\section{Acknowledgments}

This study was carried out with the support of the Coordination of Improvement of Higher Education Personnel - Brazil (CAPES) - Financing Code 001 (PNPD scholarship for E.F. Costa; PhD scholarship for G.O. Werlang and MSc scholarship for T.R. Vieira).

\section{References}

Álvarez-Ordóñez, A., Fernández, A., Bernardo, A., \& López, M. (2010). Arginine and lysine decarboxylases and the Acid Tolerance Response of Salmonella Typhimurium. International Journal of Food Microbiology, 136(3), 278-282. doi: 10.1016/j. ijfoodmicro.2009.09.024

Back, K.-H., Kim, S.-O., Park, K.-H., Chung, M.-S., \& Kang, D.-H. (2012). Spray method for recovery of heat-injured Salmonella Typhimurium and Listeria monocytogenes. Journal of Food Protection, 75(10), 1867-1872. doi: 10.4315/0362-028x.jfp-11-512

Barbosa, M. S., Todorov, S. D., Jurkiewicz, C. H., \& Franco, B. D. G. M. (2015). Bacteriocin production by Lactobacillus curvatus $\mathrm{MBSa} 2$ entrapped in calcium alginate during ripening of salami for control of Listeria monocytogenes. Food Control, 47(1), 147-153. doi: 10.1016/j.foodcont.2014.07.005

Beales, N. (2004). Adaptation of microorganisms to cold temperatures, weak acid preservatives, low $\mathrm{pH}$, and osmotic stress: a review. Comprehensive Reviews in Food Science and Food Safety, 3(1), 1-20. doi: 10. 1111/j.1541-4337.2004.tb00057.x

Caccioppoli, J., Custódio, F. B., Vieira, S. M., Coelho, J. V., \& Glória, M. B. A. (2006). Aminas bioativas e características físico-químicas de salames tipo italiano. Arquivo Brasileiro de Medicina Veterinaria e Zootecnia, 58(4), 648-657. doi: 10.1590/S010209352006000400029

Campagnol, P. C. B., Fries, L. L. M., Terra, N. N., Santos, B. A. dos, Furtado, A. S., Toneto, E. R. L., \& Campos, R. M. L. D. (2011). The influence of achyrocline satureioides (" Marcela") extract on the lipid oxidation of salami. Ciência e Tecnologia de Alimentos, 31(1), 101-105. doi: 10.1590/S010120612011000100013

Chang, V. P., Mills, E. W., \& Cutter, C. N. (2003). Comparison of recovery methods for freeze-injured Listeria monocytogenes, Salmonella Typhimurium, and Campylobacter coli in cell suspensions and associated with pork surfaces. Journal of Food Protection, 66(5), 798-803. doi: 10.4315/0362028X-66 .5.798

Chasco, J., Lizaso, G., \& Beriain, M. J. (1996). Cured colour development during sausage processing. Meat Science, 44(3), 203-211. doi: 10.1016/S03091740(96)00092-7

Cirolini, A., Fries, L. L. M., Terra, N. N., Milani, L. I. G., Urnau, D., Santos, B. A. dos, ... Rezer, A. P. de S. (2010). Salame tipo italiano elaborado com culturas starters nativas. Ciência e Tecnologia de Alimentos, 30(1), 171-179. doi: 10.1590/S010120612010000500026

Coroller, L., Kan-King-Yu, D., Leguerinel, I., Mafart, P., \& Membré, J. M. (2012). Modelling of growth, growth/no-growth interface and nonthermal inactivation areas of Listeria in foods. International Journal of Food Microbiology, 152(3), 139-152. doi: 10.1016/j.ijfoodmicro.2011.09.023

Ferreira, F. S., Horvath, M. B., \& Tondo, E. C. (2013). Assessing the growth and recovery of Salmonella Enteritidis SE86 after sodium dichloroisocyanurate exposure. Brazilian Journal of Microbiology, 44(3), 785-790. doi: 10.1590/S1517-83822013000300018

Fieira, C., Marchi, J. F., Marafão, D., \& Alfaro, A. T. da. (2018). The impact of the partial replacement of sodium chloride in the development of starter cultures during Italian salami production. Brazilian Journal of Food Technology, 21(1), 1-8. doi: 10.1590/19816723.03615

Hwang, C. A., Porto-Fett, A. C. S., Juneja, V. K., Ingham, S. C., Ingham, B. H., \& Luchansky, J. B. (2009). Modeling the survival of Escherichia coli O157:H7, Listeria monocytogenes, and Salmonella Typhimurium during fermentation, drying, and storage of soudjouk-style fermented sausage. International Journal of Food Microbiology, 129(3), 244-252. doi: 10.1016/j.ijfoodmicro.2008.12.003

Instrução Normativa $n^{\circ} 22$, de 31 de julho de 2000. Aprova o Regulamento Técnico de Identidade e Qualidade de de Copa, de Jerked Beef, de Presunto tipo Parma, de Presunto Cru, de Salame, de Salaminho, de Salaminho tipo Alemão, de Salame tipo Calabrês, de Salame tipo Friolano, de Salame tipo Napolitano, de Salame tipo hamburguês, de Salame tipo Italiano, de Salame tipo Milano, de Lingüiça Colonial e Pepperoni. Diário Oficial da União, Brasília. Recuperado de http://extranet. agricultura.gov.br/sislegis-consulta/ consultarLegislacao.do?operacao $=$ visualizar\&id $=$ 2239 
Kang, D. H., \& Fung, D. Y. C. (2000). Application of thin agar layer method for recovery of injured Salmonella typhimurium. International Journal of Food Microbiology, 54(1-2), 127-132. doi: 10.1016/ S0168-1605(99)00174-9

Kang, D. H., \& Siragusa, G. R. (1999). Agar underlay method for recovery of sublethally heat-injured bacteria. Applied and Environmental Microbiology, 65(12), 5334-5337. doi: 10.1128/aem.65.12.5334-

Lindqvist, R., \& Lindblad, M. (2009). Inactivation of Escherichia coli, Listeria monocytogenes and Yersinia enterocolitica in fermented sausages during maturation/storage. International Journal of Food Microbiology, 129(1), 59-67. doi: 10.1016/j. ijfoodmicro.2008.11.011

Mataragas, M., Bellio, A., Rovetto, F., Astegiano, S., Greci, C., Hertel, C.,... Cocolin, L. (2015). Quantification of persistence of the food-borne pathogens Listeria monocytogenes and Salmonella enterica during manufacture of Italian fermented sausages. Food Control, 47(1), 552-559. doi: 10.1016/ j.foodcont.2014.07.058

Mauriello, G., Casaburi, A., Blaiotta, G., \& Villani, F. (2004). Isolation and technological properties of coagulase negative staphylococci from fermented sausages of Southern Italy. Meat Science, 67(1), 149158. doi: 10.1016/j.meatsci.2003.10.003

Ministério da Saúde (2019). Surtos de doenças transmitidas por alimentos no Brasil. Recuperado de http://portalarquivos2.saude.gov.br/images/ pdf/2019/fevereiro/15/Apresenta----o-Surtos-DTA--Fevereiro-2019.pdf

Nightingale, K. K., Thippareddi, H., Phebus, R. K., Marsden, J. L., \& Nutsch, A. L. (2006). Validation of a traditional Italian-Style Salami manufacturing process for control of Salmonella and Listeria monocytogenes. Journal of Food Protection, 69(4), 794-800. doi: 10.4315/0362-028x-69.4.794
Quinn, P. J., Markey, B. K., Leonard, F. C., Hartigan, P. J., Fanning, S., \& Fitzpatrick, E. S. (2011). Veterinary Microbiology and microbial disease. New Jersey: Wiley-Blackwell

Resolução RDC $n^{\circ}$ 12, de 2 de janeiro de 2001. Aprova o Regulamento Técnico Sobre Padrões Microbiológicos para Alimentos. Diário Oficial da União, Brasília. Recuperado de http://portal. anvisa. gov.br/documents/33880/2568070/RDC_12_2001. pdf/15ffddf6-3767-4527-bfac-740a0400829b

Riordan, D. C. R., Duffy, G., Sheridan, J. J., Eblen, B. S., Whiting, R. C., Blair, I. A. N. S., \& Mcdowelv, D. A. (1998). Survival of Escherichia coli 0157: H7 during the manufacture of pepperoni. Journal of Food Protection, 61(2), 146-151. doi: 10.4315/0362028x-61.2.146

Roccato, A., Uyttendaele, M., Barrucci, F., Cibin, V., Favretti, M., Cereser, A.,... Ricci, A. (2017). Artisanal Italian salami and soppresse: identification of control strategies to manage microbiological hazards. Food Microbiology, 61(1), 5-13. doi: 10.1016/j.fm.2016.07.010

Santa, O. R. D., Macedo, R. E. F. de, Santa, H. S. D., Zanette, C. M., Freitas, R. J. S. de, \& Terra, N. N. (2014). Use of starter cultures isolated from native microbiota of artisanal sausage in the production of Italian sausage. Food Science and Technology, 34(4), 780-786. doi: 10.1590/1678-457X.6467

Werlang, G. O., Haubert, L., Peter, C. M., \& Cardoso, M. (2019). Isolation of Salmonella Typhimurium, Listeria monocytogenes and coagulase-positive Staphylococcus from salami sold at street fairs in Porto Alegre, Brazil. Arquivos do Instituto Biológico, 86(1), 1-6. doi: 10.1590/1808-1657000072019

Wu, V. C. H., Fung, D. Y. C., \& Kang, D. H. (2001). Evaluation of thin agar layer method for recovery of cold-injured foodborne pathogens. Journal of Rapid Methods and Automation in Microbiology, 9(1), 1125. doi: 10.1111/j.1745-4581.2001.tb00224.x 